\title{
Working in Psychiatry: Staff Perception of the Brazzaville Hospital and University Center
}

\author{
Mbou Essie Darius1,2, Gandou Paul1,3, Mouanga Alain'1,3, Matini Prefina1, Gontran Ondzotto1, \\ Ntsiba Honoré1, Ibara Jean-Rosaire1
}

${ }^{1}$ Faculty of Health Sciences, Marien Ngouabi University, Brazzaville, Republic of the Congo

${ }^{2}$ General Management of Health Care Services, Ministry of Public Health, Brazzaville, Republic of the Congo

${ }^{3}$ Department of Psychiatry, Brazzaville Hospital and University Centre, Brazzaville, Republic of the Congo

Email: eryxdarius40@gmail.com

How to cite this paper: Darius, M.E., Paul, G., Alain, M., Prefina, M., Ondzotto, G., Honoré, N. and Jean-Rosaire, I. (2020) Working in Psychiatry: Staff Perception of the Brazzaville Hospital and University Center. Open Journal of Psychiatry, 10, 39-44. https://doi.org/10.4236/ojpsych.2020.102005

Received: January 5, 2020

Accepted: February 21, 2020

Published: February 24, 2020

Copyright $\odot 2020$ by author(s) and Scientific Research Publishing Inc. This work is licensed under the Creative Commons Attribution International License (CC BY 4.0).

http://creativecommons.org/licenses/by/4.0/

\begin{abstract}
Background: In Congo-Brazzaville, there is a lake of mental healthcare provider and facilities specialized on psychiatric care: only two psychiatrists and one psychiatric department around the country. Poor appreciation of their role and work environment can negatively impact the esteem of psychiatric staff and lead to stigma and discrimination towards patients. Aims: The study aimed to assess the perception of the staff of the only psychiatric service in Congo. Material and methods: We conducted a cross-sectional descriptive, prospective survey; conducted among the psychiatric staff of the Brazzaville University Hospital in September 2019. An anonymous individual questionnaire was administered to collect: 1) socio-professional data, 2) perceptions (assignment, role, workload and working conditions), and 3) identify the main problems of the service. Averages and frequencies were calculated on Epi info 7.2.2.6. Results: Thirty out of 42 staff had responded (71.4\%); 16 were male and at their first psychiatric assignment (28/30), with an average age of $44.7 \pm 7$ and seniority of $8.4 \pm 8.3$ years. Among them: one psychiatrist, two psychologists, and 19 nurses. Their assignment in psychiatry was well perceived in $93.3 \%$ (27/30), as well as their role (the importance of psychiatric care and psychiatry). Working conditions were perceived as poor: precarious hygiene (93.3\%), cohabitation with dangerous patients (82.1\%), heavy workload due to lack of staff $(100 \%)$. Of their professional future, $23.3 \%(7 / 30)$ were considering leaving. Conclusion: Almost all psychiatric staff had a good perception of their role and psychiatry, but not of the working conditions. Local measures to improve working conditions must be carried out to improve the attractiveness of psychiatry and the quality of care.
\end{abstract}

\section{Keywords}

Psychiatric Health Care Provider, Working Conditions, Perception, 
Brazzaville

\section{Introduction}

People with psychiatric illnesses are often discriminated against and stigmatized in several societies [1] [2] [3] [4] [5]. This discrimination can extend to psychiatry as a medical discipline and to the staff in charge of these patients [6] [7] and is known as "associative stigma, with the consequence that psychiatry [8] is disaffected and that psychiatric staff has a poor perception of their own working environment. The vicious circle of poor quality of care and stigmatization of patients by demotivated staff is then established [9] [10] [11] [12] [13]. In order to help remedy this situation, we evaluated the perception of psychiatric work by the staff of the only one psychiatric department of psychiatry in Brazzaville University Hospital.

\section{Materials and Methods}

\subsection{Study Design}

We conducted a mixed cross-sectional, prospective and descriptive survey. Between August and September 2019 all staff of the only national psychiatric service located at Brazzaville University Hospital was included for individual interview using an open and closed anonymous questionnaire.

\subsection{Variables Used for Analyses}

The groups of variables studied were: 1) socio-professional (age, sex, rank, service of origin and rank of psychiatric assignment), 2) perceptions (psychiatric assignment, usefulness of psychiatric care and psychiatry, workload and working conditions in psychiatry), 3) synthesis of the main problems of the service and 4) the professional future in one year.

\subsection{Statistical Analyses}

Descriptive statistics described study population characteristics: the average age and seniority were calculated; the perceptions of staff were classified into headings according to the staff's responses and presented in frequency. The data was recorded on Epi info 7.2.2.2.6.

\section{Results}

Out of 42 staff regularly assigned to the CHUB Psychiatry Department, 30 were interviewed (71.4\%), including 16 men and 14 females. The 12 remain, 7 refused to participate at study and 5 in congès. The average age was $44.7 \pm 7$ years (extreme 26 and 56 years), median and mode at 44 years. The staff qualification included: five surface technicians, three secretaries, nineteen nurses, two psychologists and one psychiatrist. Fourteen care providers had begun their careers in 
psychiatry; 16 were on their first assignment in psychiatry. The average seniority was $8.4 \pm 8.7$ years and the median were 5 years.

On the perception of their assignment $27 / 30$ (90\%) do not describe any particular circumstances during their assignment, for the other 3 there was a conflict or a fault that involved them. Thus, for these 3 (7\%), the decision of their assignment was a "sanction against me", for the others (93\%) a normal decision $(24 / 30)$ is requested by the staff themselves (3/30). Twenty-six agents (86.7\%) perceived their presence in psychiatry as very useful, for 4 they were useless in psychiatry.

The perception of psychiatry was based on the need for psychiatric care: 29/30 agents $(96.7 \%)$ perceived it as necessary, for one they bring nothing. Then on the encouragement of a relative to do psychiatry: Twenty-five agents (83.3\%) said they were ready to encourage a relative who wants to specialize in psychiatry against five.

The workload was perceived as hard to too hard by 26 staff ( $86.7 \%)$, and that this should require an additional bonus.

Concerning working conditions, 24 staff (82.1\%) considered that cohabitation with patients put them at risk because of the risk of violence. All 30 staff reported that they had been victims or witnesses of the physical assault of staff by a patient. For hygiene and equipment, 28 (93.3\%) officers find the working conditions unacceptable, for two these conditions do not differ from other services. We then asked the staff to summarize the main problems of the psychiatry department by making their own analysis. The lack of staff is unanimously recognized as a major problem by the staff (Figure 1).

From their professional future in one year, seven staff wanted to leave psychiatry; they had between 1 and 10 years of seniority and among them a nurse manager and two FDI (Table 1).

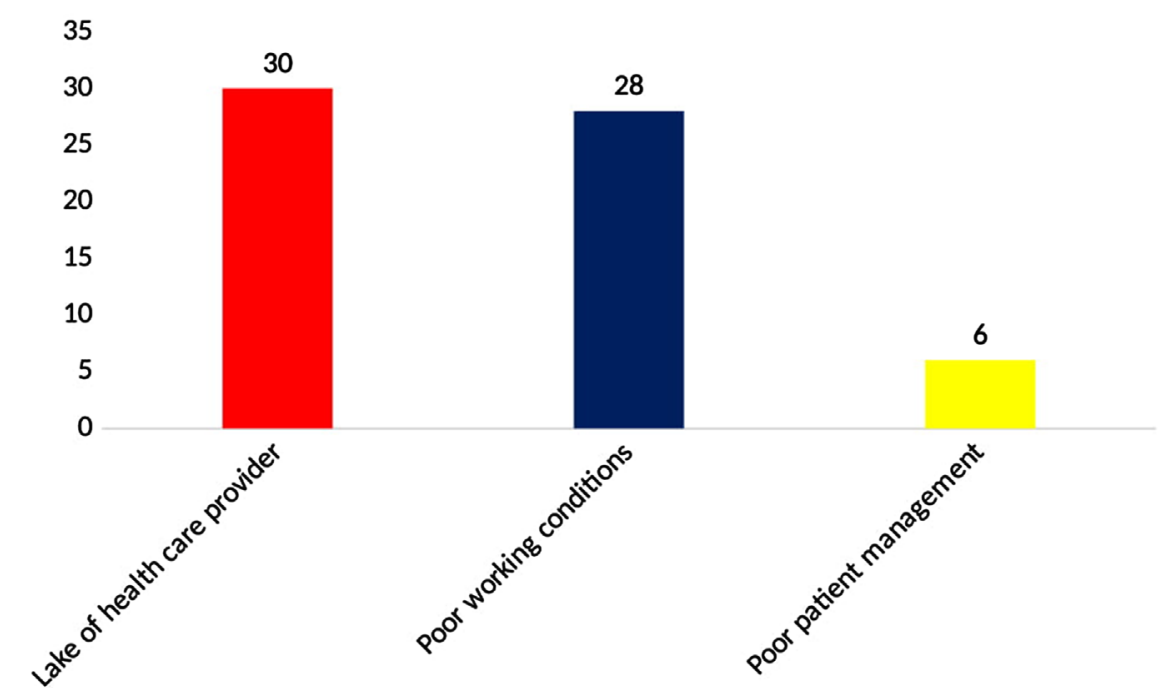

Figure 1. Main service issues according to staff (each personal might evocate one or more main problem). 
Table 1. Professional future in one year's time, grade and seniority.

\begin{tabular}{|c|c|c|c|c|}
\hline \multicolumn{5}{|c|}{ Professional future } \\
\hline & $\begin{array}{l}\text { I want to deepen my } \\
\text { knowledge of psychiatry }\end{array}$ & I want to leave & I want to stay & Total \\
\hline \multicolumn{5}{|c|}{ Rank/qualification } \\
\hline None & 1 & 2 & 2 & 5 \\
\hline Nursery & - & 1 & - & 1 \\
\hline Secretary & 1 & 1 & 1 & 3 \\
\hline $\mathrm{ATS}^{\mathrm{a}}$ & 1 & - & - & 1 \\
\hline $\mathrm{IDE}^{\mathrm{b}}$ & 4 & 2 & 4 & 10 \\
\hline $\mathrm{LSI}^{\mathrm{c}}$ & 2 & 1 & 2 & 5 \\
\hline Psychologist & 1 & - & - & 1 \\
\hline Psychiatrist & - & - & 1 & 1 \\
\hline Total & 10 & 7 & 10 & $27^{*}$ \\
\hline \multicolumn{5}{|l|}{ Seniority (years) } \\
\hline $1-10$ & 7 & 7 & 6 & 20 \\
\hline $11-20$ & 1 & - & 3 & 4 \\
\hline $21-30$ & 2 & - & - & 2 \\
\hline $31+$ & - & - & 1 & 1 \\
\hline Total & 10 & 7 & 10 & $27^{*}$ \\
\hline
\end{tabular}

$\mathrm{a}=$ health technical officer, $\mathrm{b}=$ state registered nurse, $\mathrm{c}=$ nursing licensee. ${ }^{\star} 3$ officers did not provide information on future career prospects in one year.

\section{Discussion}

Our sample, although small in size, represents the only population of staff caring for the mentally ill because Congo has only one mental health care service. The Mental health GAP (mhGAP) action plan initiated by WHO in 2008 to improve the integration of mental health care has not yet been implemented. The anonymity of the questionnaires and the individual interview by two investigators external to the service were intended to reduce self-censorship and the copying of responses.

The vast majority of our respondents had a good perception of their assignment and their own presence on the psychiatric care team; psychiatric care seemed necessary to them for the recovery of the patients. Unlike other health workers in Congo or Africa, who have no experience of modern treatments for mental illness, they prefer "traditional" care [13]. However, their workload seemed "too much" to them, which reflects the profound lack of HHR in mental health as reported by all of them (Figure 1). They are the only reference for psychiatric care in the country, with a large number of patients. The chronic lack of resources for health in general and critical for mental health may explain the poor working conditions in psychiatric services in Africa in general [14] [16]; 
almost all of our respondent report this (Figure 1). One aspect of this problem is the lack of hygiene. The lack of self-control of some mentally ill people increases the need for hygiene. Hospital hygiene should be an important budget item for psychiatric services. The other aspect of poor working conditions mentioned by our respondents was insecurity towards patients. For all of them, cohabitation with the latter is dangerous. Although these statements are underpinned by the fact that they have witnessed or been the victim of multiform aggression by patients, they carry the risk of stigmatization because not all mental patients are dangerous [3]. Therapeutic success is based on a patient-centered relationship of trust between caregiver and patient, so our respondents need anti-stigma training initiatives and patient-centered care that is developing rapidly in several Western countries [17] [18] [19] and timidly in Black Africa [13]. Seven staff (23.3\%) planned to "leave" the psychiatric ward". From the staff's point of view, this reflects suffering that must be taken into account by CHUB managers in order to improve working conditions. Staff who do not feel supported cannot provide better support to patients. The disaffection of psychiatry [20] and the stigmatizing view of other health personnel towards psychiatry [6] certainly integrates working conditions. With only two active psychiatrists, Congo cannot cope with the high morbidity of mental disorders; the attractiveness of psychiatry should, therefore, be improved.

\section{Conclusion}

The vast majority of psychiatric staff at the CHUB has a good perception of their role for the mentally ill, however, they are convinced that they are in danger towards patients and report poor hygiene conditions and an excessive workload. Local measures can be implemented to address this.

\section{Conflicts of Interest}

Authors don't declare any funding from organization or individuals and potential conflicting interest.

\section{References}

[1] Audu, I.A., Idris, S.H., Olisah, V.O., et al. (2011) Stigmatization of People with Mental Illness among Inhabitants of a Rural Community in Northern Nigeria. International Journal of Social Psychiatry, 59, 55-60. https://doi.org/10.1177/0020764011423180

[2] Hayward, P. (1997) Stigma and Mental Illness: A Review and Critique. Journal of Mental Health, 6, 345-354. https://doi.org/10.1080/09638239718671

[3] Senon, J.-L., Manzanera, C., Humeau, M. and Gotzamanis, L. (2006) Les malades mentaux sont-ils plus violents que les citoyens ordinaires? L' information psychiatrique, 82, 645. https://doi.org/10.3917/inpsy.8208.0645

[4] Lovell, A.M., Cook, J. and Velpry, L. (2008) La violence envers les personnes atteintes de troubles mentaux: Revue de la littérature et des notions connexes. Revue d Épidémiologie et de Santé Publique, 56, 197-207.

https://doi.org/10.1016/j.respe.2008.03.119 
[5] Bichsel, D.N. (2017) La stigmatisation: Un problème fréquent aux conséquences multiples. Revue Médicale Suisse, 13, 478-481.

[6] Sebanne, D. (2005) Les internes de psychiatrie vus par leurs confreres: Jugés mais prejudges. L' information Psychiatrique, 91, 417-421.

[7] Gronholm, P., Henderson, C., Deb, T. and Thornicroft, G. (2017) Interventions to Reduce Discrimination and Stigma: The State of the Art. Social Psychiatry and Psychiatric Epidemiology, 52, 249-258. https://doi.org/10.1007/s00127-017-1341-9

[8] OMS (2013) plan d'action pour la santé mentale 2013-2020 [Internet]. https://apps.who.int/iris/bitstream/handle/10665/89969/9789242506020_fre.pdf;jses sionid=77961BF4931D8C48040CA7C13DC15810? sequence $=1$

[9] Kapungue, A., Cooper, S., Mayeya, J., Mwandza, J., Mwape, L., Skwese, A., et al. (2011) Attitudes of Primary Health Care Providers towards People with Mental Illness: Evidence from Two Districts in Zambia. African Journal of Psychiatry, 14, 290-297. https://doi.org/10.4314/ajpsy.v14i4.6

[10] Sow, A., Van Dormael, M., Criel, B., Condé, S., Dewez, M. and De Spiegelaere, M. (2018) Stigmatisation de la maladie mentale par les étudiants en medecine en Guinnée Conakry. Santé Publique, 30, 253-261.

https://doi.org/10.3917/spub.182.0253

[11] Schulze, B. (2007) A Review of the Evidence on an Intricate Relationship. International Review of Psychiatry, 19, 137-155.

https://doi.org/10.1080/09540260701278929

[12] Ewhrudjakpor, C. (2009) Knowledge, Beliefs and Attitudes of Health Care Providers towards the Mentally Ill in Delta State, Nigeria. Studies on Ethno-Medicine, 3, 19-25. https://doi.org/10.1080/09735070.2009.11886332

[13] Sow, A., Van Dormael, M., Criel, B. and De Spiegelaere, M. (2019) Integration de la santé mentale dans les centres de santé communautaires en Guinée Conakry. Santé Publique, 31, 305-313. https://doi.org/10.3917/spub.192.0305

[14] Semrau, M., Evans-Lacko, S., Alem, A., Ayuso-Mateos, J.L., Chisholm, D., Gureje, O., et al. (2015) Strengthening Mental Health Systems in Low- and Middle-Income Countries: The Emerald Programme. BMC Medicine, 13, 79. https://doi.org/10.1186/s12916-015-0309-4

[15] OMS (2015) Atlas de la santé mentale 2014 [Internet]. WHO. http://www.who.int/mental_health/evidence/atlas/mental_health_atlas_2014/fr

[16] Abdulmalik, J., Olayiwola, S., Docrat, S., Lund, C., Chisholm, D. and Gureje, O. (2019) Sustainable Financing Mechanisms for Strengthening Mental Health Systems in Nigeria. International Journal of Mental Health Systems, 13, 38. https://doi.org/10.1186/s13033-019-0293-8

[17] Knaak, S., Modgill, G. and Patten, S. (2014) Key Ingredients of Anti-Stigma Programs for Health Care Providers: A Data Synthesis of Evaluative Studies. Canadian Journal of Psychiatry, 59, S19-S29. https://doi.org/10.1177/070674371405901S06

[18] Gask, L. and Coventry, P. (2012) Person-Centred Mental Health Care: The Challenge of Implementation. Epidemiology and Psychiatric Sciences, 21, 139-144. https://doi.org/10.1017/S2045796012000078

[19] Paresh, D. and Lakdawala, M. (2015) Doctor-Patient Relationship in Psychiatry. Mens Sana Monographs, 13, 82-90. https://doi.org/10.4103/0973-1229.153308

[20] Rouprêt, M., Hupertan, V. and Chartier-Kastler, E. (2005) Souhaits professionnels de 600 étudiants en médecine français préparant les épreuves classantes nationales. La Presse Médicale, 34, 786-790. https://doi.org/10.1016/S0755-4982(05)84042-4 